\title{
What if Eurasian jay Garrulus glandarius would larder acorns instead of scatter them?
}

\author{
Przemysław Kurek ${ }^{(1)}$, \\ Dorota Dobrowolska ${ }^{(2)}$, \\ Blanka Wiatrowska ${ }^{(3)}$, \\ Łukasz Dylewski ${ }^{(4)}$
}

\begin{abstract}
Jays usually store acorns at separate sites, but in some cases a part of jay's caches consists of more than one acorn. Storing acorns separately (scatter hoarding) or in clusters (larder hoarding) seems to be an important factor for further survival of seeds and seedlings. Scatter hoarding is favorable for jays, but what would happen if jays prepared caches consisting of more than one acorn? We put a following question: what is the importance and impact of acorn concentration per cache for the seedlings' mortality and their growth characteristics? In 2013 an experimental plot was established. 1400 acorns of Quercus robur $\mathrm{L}$. were sewed in 600 holes in three combinations called growing mode - singly, in twos and in fours. The mortality of seedlings depended on growing mode $(Z=6.24, P<0.001)$ and year $(Z=-2.42, P=0.016)$. In the third year of the experiment the mortality of seedlings growing from acorns sewed in fours reached almost $90 \%$, while in the case of seedlings growing separately the mortality was stable, reaching no more than $23 \%$. Both growing mode $(F=26.49, P<0.001)$ and year $(F=52.59, P<0.001)$ had a significant impact on seedling growth increment. Seedlings growing in fours had a significantly higher growth increment than these growing separately and in twos. We concluded that seedlings growing separately had a higher survival rate, but lower growth increment than those coming from acorns sewed in clumps.
\end{abstract}

Keywords: Eurasian Jay, Acorns, Scatter Hoarding, Larder Hoarding, Seedlings Survival, Seed Dispersal

4 or $5 \mathrm{~km}$ to storage sites (Vander Wall 1990), although it seems that this distance is often much shorter (Chettleburgh 1952, Gómez 2003). Moreover, in autumn jays gather great quantities of oak acorns ranging from 2200 to 5700 (Chettleburgh 1952, Kollmann \& Schill 1996). Also, North American jays collect up to 3000-5000 acorns in a single year (Johnson et al. 2009). Consequently, we may observe an effective renewing and chorological expansion of several Quercus species as a result of a close, mutualistic relationship between jays and oaks all over jays' European range (Dobrowolska 2006, Pons \& Pausas 2006, Pons \& Pausas 2007, Myczko et al. 2014, Daniel- $\square$ (1) Department of Plant Ecology and Environmental Protection, Adam Mickiewicz University, Umultowska 89, 61-614 Poznań (Poland); (2) Department of Forest Ecology, Forest Research Institute, Braci Leśnej 3, 05-090 Sękocin Stary (Poland); (3) Department of Forest Botany, Poznań University of Life Sciences, Wojska Polskiego 71D, Poznań 60-625 (Poland); (4) Institute of Zoology, Poznań University of Life Sciences, Wojska Polskiego 71C, Poznań 60-625 (Poland)

@ Przemyslaw Kurek (przkur1@amu.edu.pl)

Received: Mar 20, 2018 - Accepted: Aug 02, 2018

Citation: Kurek P, Dobrowolska D, Wiatrowska B, Dylewski L (2018). What if Eurasian jay Garrulus glandarius would larder acorns instead of scatter them?iForest 11: 685-689. - doi: 10.3832/ifor2793-011 [online 2018-10-23]

Communicated by: Massimo Faccoli ewicz et al. 2016, Kurek \& Dobrowolska 2016).

Two main strategies of food hoarding in birds may be recognized: larder hoarding and scatter hoarding (Bossema 1979, Vander Wall 1990, Johnson et al. 2009). Larder hoarding is the caching of all food at one site. Scatter hoarding describes the phenomenon of burying food items widely spaced. A mixed strategy with few seeds stored together in many stores scattered in space is also recognized (Vander Wall 1990). Jays usually store each food item (i.e., acorn) at a separate site (scatter hoarding) instead of clumped (larder hoarding), just below the ground surface in individual, widely-spaced cache sites to reduce pilferage and increase the probability of cache recovery (Bossema 1979, Bartlow et al. 2011). In many systems this behaviour also contributes significantly to dispersal, germination and establishment of seedlings, when scatter hoarders fail to recover their caches (Vander Wall 1990). Frequently, cached seeds are not recovered and ultimately germinate.

The seed and seedling stages are the most vulnerable for most plant species and processes operating during these stages are thereby especially important for plant regeneration (Gómez 2004). The way of seed storage (separately or in clusters) seems to be an important factor for seed and seedling survival, because scattering seems to be clearly more beneficial to the 
trees (Howe 1989). In the case of jays, pilferage has probably led to storing seeds separately (Bartlow et al. 2011, Legg \& Clayton 2014), but some authors reported that a part of jay's caches may consist of more than one seed/acorn (Nilsson 1985). Scatter hoarding strategy is favorable for jays, but what would happen if jays prepared stores of acorns consisting of more than one seed? Is mixed strategy also favorable for acorns and thus for seedling and sapling survival? Answering such questions in jay-oak interactions may have relevant implications for understanding oak renewing processes. In most papers on the effect of seed removal, seed predation and further seedling survival observations were conducted only for a short period of time with no data about the fate of seedlings. There is a lack of data concerning the fate of seedlings several years after germination. This paper reports the results of a field experiment led in three consecutive years after germination simulating the mixed strategy of acorns hoarded in caches consisting of 1,2 and 4 acorns.

According to model presented by Janzen (1970), seed and seedling concentration has usually a negative impact on further survival and establishment of new plants. Many reports confirmed that the seedlings' density may influence the mortality rate (Augspurger \& Kelly 1984, Jinks \& Mason 1998, Lambers et al. 2002, Lu et al. 2015) and affect biometric characteristics of the seedlings (Bullock 1981). Thus, we put a following question: what is the impact of acorn concentration per cache on the fate of seedlings (seedling mortality) and their growth characteristics? However, we suspected that growing in high densities, as seedlings usually do in early stages of their establishment, does not mean the same as growing in scattered clumps, which may be profitable for plants (Bullock 1981). Taking into consideration potential advantages of growing in clumps (i.e., grafting, mutual shading), we tested the following hypotheses: (1) the mortality rate will depend on seed concentration per cache and it will decline as acorn concentration per cache increases; (2) the height increment of seedlings will increase as acorn/seedling concentration per cache gets higher; and (3) the increment of survived seedlings will increase after the death of other seedlings from the same cache - we call it the "release effect".

\section{Methods}

The study was carried out in the Olsztyn Lakeland (Nowe Ramuki Forest District Fig. 1), among lowland forest complex in north-eastern Poland. It is situated in the Łyna River Valley (289 km long), $200 \mathrm{~km}$ north of Warsaw $\left(53.54^{\circ}\right.$ to $53.69^{\circ} \mathrm{N}, 20.42^{\circ}$ to $20.57^{\circ} \mathrm{E}$; altitude up to $200 \mathrm{~m}$ a.s.l.) connecting two lakes: Łańskie $\left(10.7 \mathrm{~km}^{2}\right)$ and Pluszne $\left(9.0 \mathrm{~km}^{2}\right)$. In the north, soils are clay-dominated of moraine origin with developed agriculture. In the south, sands and gravel are dominant (Kondracki 2009) and the landscape is mostly covered by Pinus sylvestris L. and Picea abies (L.) Karst. forests with Quercus robur L. as an admixture species. The succession of oaks by jays under the canopy of the Scots pine is evident and widespread in this region. The oak renewal is viable and numerous, mostly present as separately occurring seedlings.

In October 2013 an experimental plot was established. The entire plot was protected from rodents with a steel net with a mesh ca. $0.4 \mathrm{~cm}$ attached to the ground. On the plot 600 holes were prepared ( 15 holes in 40 rows) and 1400 acorns of Quercus robur were sewed in them. Each hole had its own coordinates (hole number and row number) which enabled to precisely establish the fate of seedlings in each hole. We sewed acorns in three types of concentra-

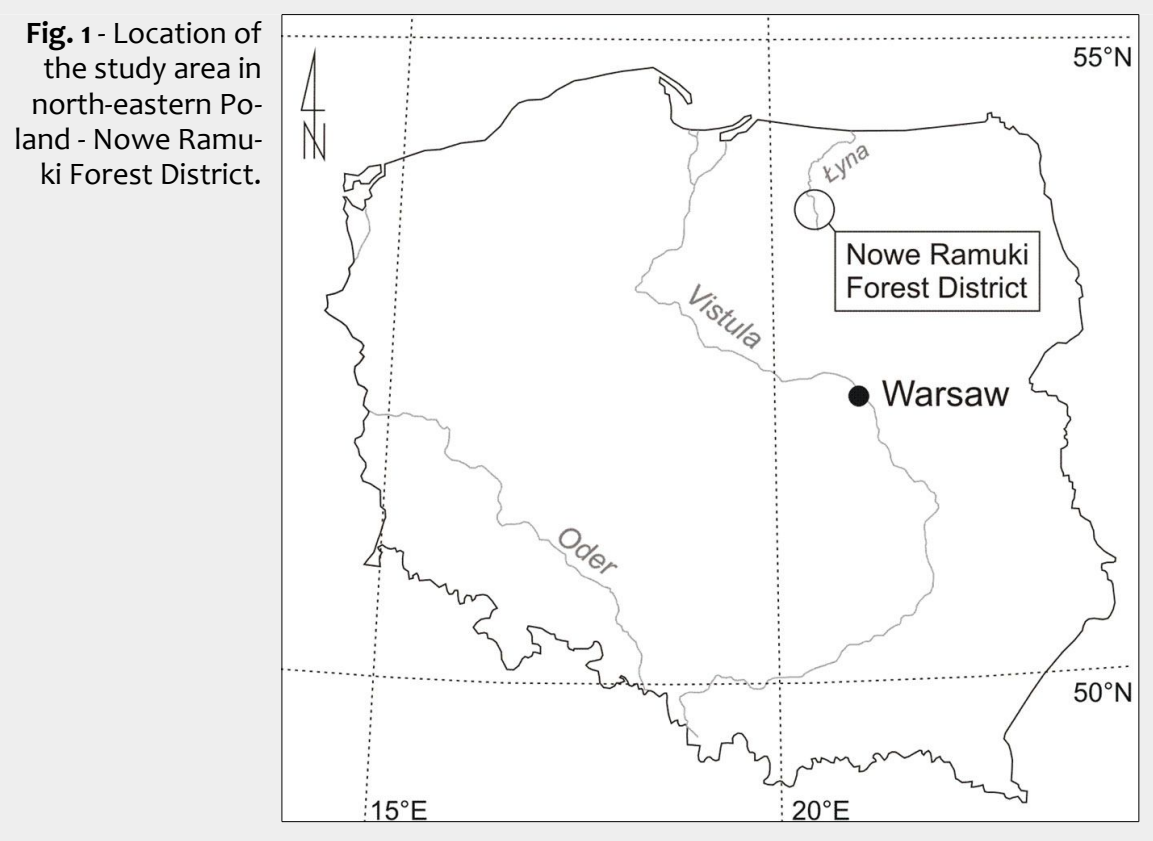

tion called growing mode (one, two and four acorns per cache). This means that in 200 holes 200 acorns were sewed (single acorn per cache), in the next 200 holes 400 acorns (two acorns per cache) and 800 acorns in the following 200 holes (four acorns per cache).

In October 2014, 2015 and 2016 seedlings were counted to get information about the survival rate after each year of their growth in three different dispersal modes. After third year of the experiment (October 2016) the total height and height increment from each year were estimated with an accuracy of $1 \mathrm{~mm}$ in each seedling. To check if the "release effect" (see hypothesis \#3) exists, we compared the growth increments of seedlings growing in twos with seedling growing singly after the death of other seedlings from the same cache (pairs) and with seedlings growing singly from the beginning of the experiment.

We used a generalized linear model with binomial error and pairwise comparison to verify the effects of growing mode, year and interaction between growing mode and year on seedlings mortality. We used two-way ANOVA with Tukey's post-hoc test to verify the effect of growing mode, year and interaction between them on growth increment of seedlings. The data was transformed with logarithmic functions to obtain a normal or at least symmetric distribution. All analyses were carried out in $\mathrm{R}$ ver. 3.3.2 (R Core Development Team 2016). The pairwise comparison was performed using the "Ismeans" package (Lenth 2016) and the data visualisation was performed by the "ggplot2" package (Wickham 2009).

\section{Results}

The mortality of seedlings depended significantly on the growing mode $(Z=6.24, P$ $<0.001)$ and year $(Z=-2.42, P=0.016)$. During all three years the greatest cumulative mortality was detected in the case of seedlings growing from acorns sewed in fours per cache (Fig. 2). The number of died down seedlings gradually increased after the first and second years (2014 and 2015), but the greatest mortality was observed after the third year (2016), when the mortality of seedlings (especially from acorns sewed in twos and in fours) suddenly increased. In the third year of the experiment, the mortality in the case of seedlings growing from acorns sewed in fours reached almost 90\%, while the mortality of seedlings growing separately was stable, reaching no more than $23 \%$.

Both growing mode and year had a significant impact on seedling growth increment (Tab. 1). In comparison to seedlings growing separately and in twos, significantly higher increments were recorded in the case of seedlings coming from the acorns that were sewed in fours (Fig. 3). No difference in increment were found between seedlings growing separately and in twos. Seedlings grew best in the first year after 
germination. Growth increments did not differ between the next two years (Fig. 3).

There were no significant differences in height increments between seedlings growing separately, in twos and growing separately after dying down of one of the pair $(F=1.11, P=0.333)$. However, mean height of seedlings growing separately and those which stayed single after dying down of one of the pair were higher (114.5 vs. $113.6 \mathrm{~mm}$, respectively) than mean height of seedlings still growing together (107.9 $\mathrm{mm})$.

\section{Discussion}

Oaks benefit from food hoarding animals that bury their acorns in suitable sites where they may establish a new plant (Vander Wall 1990). The survival rate of seeds stored in jay caches is higher, because of reduced predation from granivory species and pest pressure which prevents seedlings from drying (Gómez 2004, Pons \& Pausas 2008, Johnson et al. 2009). Jays deposit acorns in shallow subsurface caches in soil or between the soil and the litter layer and cache depth is constrained by the length of birds' bill (Vander Wall 1990). In particular, seed burial by animals strongly affects seedling establishment in many plant species. Seedlings that emerge from acorns buried in the soil or deposited close to bare soil (under litter layer) have a better start and a higher chance to survive than acorns that had fallen straight from the tree and were not buried (Seiwa et al. 2002). We tried to answer the question what was the effect of scatter or larder hoarding on seedling survival and seedling growth.

The most obvious benefit of scatter hoarding over larder hoarding is not necessarily solely related to robbery by food competitors. Seedling mortality in caches can be attributed to a variety of factors (Howe 1989, Vander Wall 1990). Seedlings' death can be caused by storage at sites inappropriate for establishment; seedlings are damaged by insects, pathogens, seed predators, seedling herbivory, animals digging up the germinants and by intraspecific competition for water and other resources (Howe 1989, Vander Wall 1990). Moreover, seedlings' density affect seedling survival and recruitment (Augspurger \& Kelly 1984, Jinks \& Mason 1998, Lambers et al. 2002, Lu et al. 2015). The neighborhood of conspecifics may increase the competition for resources (nutrient and water). In this case, especially in periods of resource demands, the mortality may be higher. In research carried out by McBride et al. (1991) the mortality during drought was much higher in 10 acorn clumps (55.2\%) than in the case of single acorns (23.9\%). Our findings also confirm that saplings may have higher mortality, when growing in groups than separately ( $90 \%$ vs. $23 \%$ ). We also found that the mortality increased as acorn concentration per cache increased, thus hypothesis \#1 was not confirmed (Fig. 2).

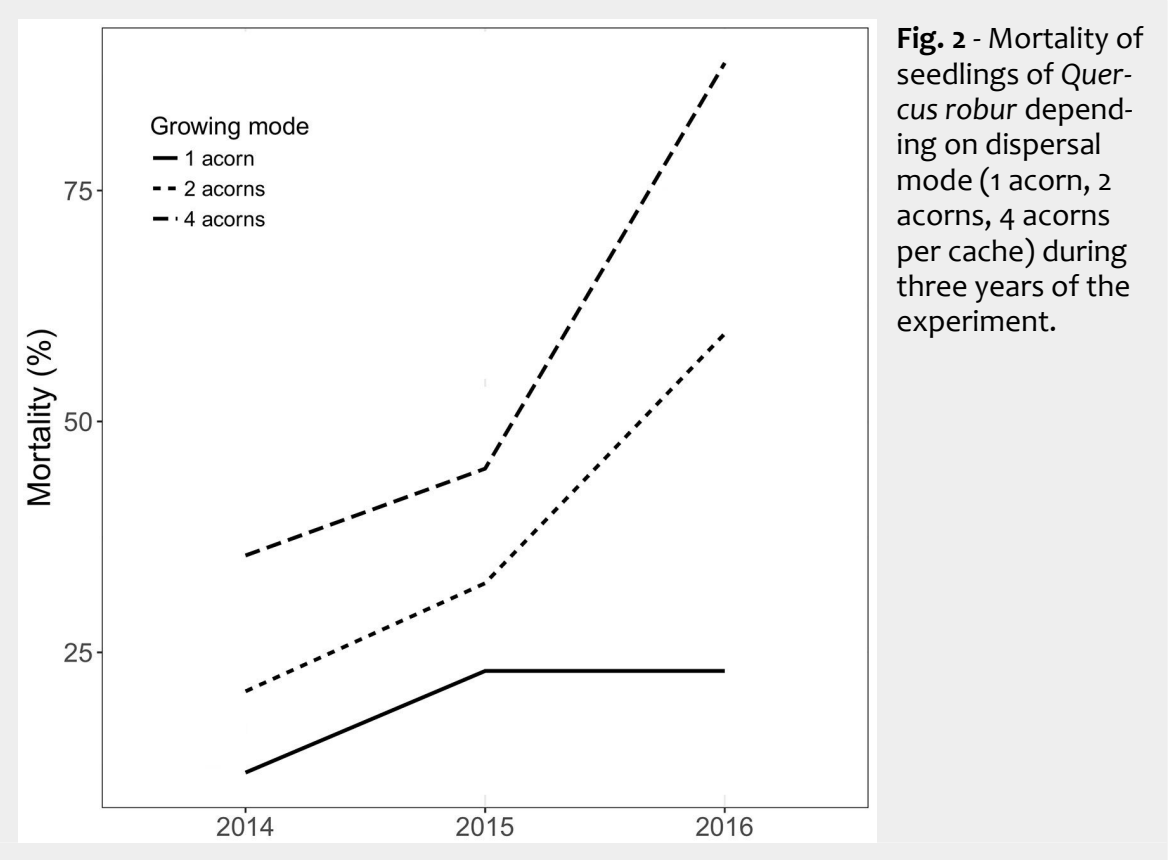

Tab. 1 - Results of ANOVA on the differences in height increment of seedlings depending on growing mode (1, 2 and 4 acorns per cache) and year (2014, 2015 and 2016).

\begin{tabular}{lccc}
\hline \multirow{2}{*}{ Effect } & \multicolumn{3}{c}{ Height increment } \\
\cline { 2 - 4 } & df & $\mathbf{F}$ & $\mathbf{P}$ \\
\hline Growing mode & 2 & 26.49 & $<0.001$ \\
Year & 2 & 52.59 & $<0.001$ \\
Interaction & 4 & 3.15 & 0.014 \\
\hline
\end{tabular}

We conclude that the seed/seedling con- in some cases growing in clumps did not afcentration per cache increases the mortal- fect the survival rate of seedlings. Saplings' ity rate in comparison to plants growing roots may contact (by grafting) and imseparately. Bossema (1979) in his research prove the nutrient intake, when growing in found that planting in clumps or separately groups. Bullock (1981) suggested that seeddid not influence the viability of acorns. lings in aggregations may profit from i.e. Therefore the chance of acorns rotting was mutual shading or grafting. Grafting was not influenced by the presence of other commonly observed among individuals/ acorns. The results cited above show that seedlings growing in clumps (Bullock 1981).

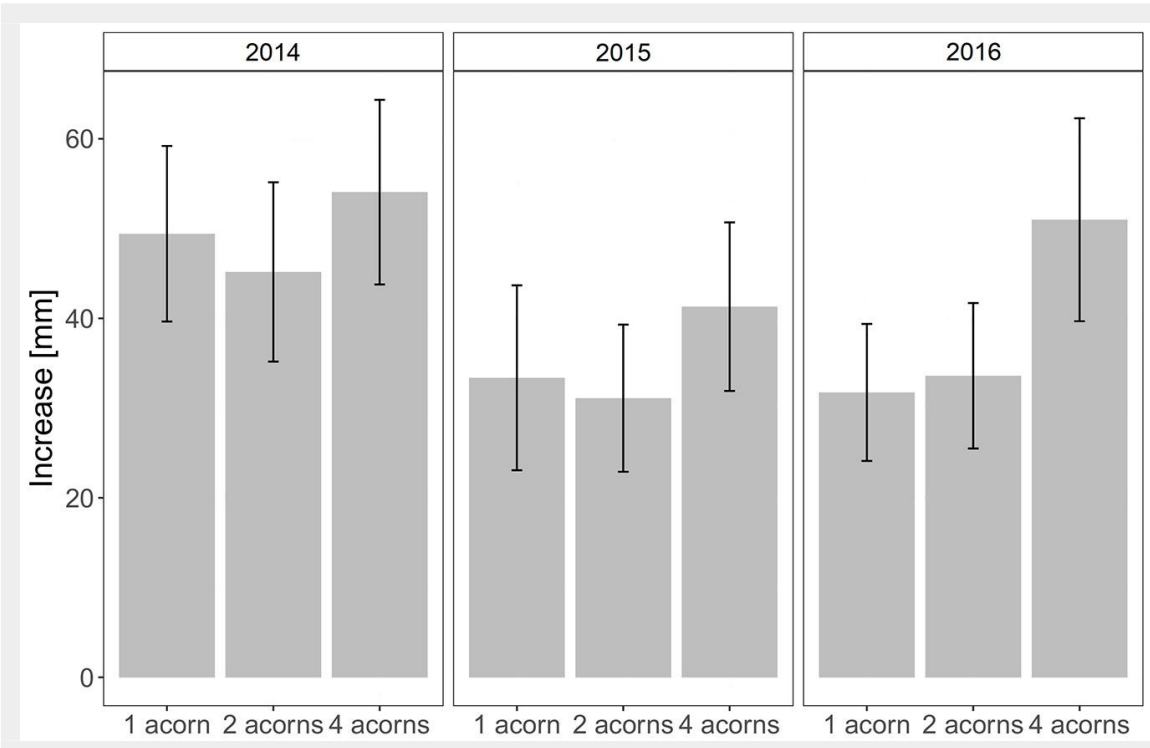

Fig. 3 - Height increments of seedlings of Quercus robur depending on dispersal mode (1 acorn, 2 acorns, 4 acorns per cache) and year (2014, 2015, 2016). 
It may be that in some cases seedlings and future saplings growing separately (no grafting observed) may have higher mortality than these growing in groups (Bullock 1981). On the other hand, we have to remember that the death of the epicoty does not mean the death of a whole seedling. In many cases in our experiment, seedlings revealed an apparent death by epicotyl caesura. Such effect may reappear in the following years, preventing the young plant's efficient growth; nonetheless, the roots are still alive and may produce shoots again.

Many studies revealed that the mortality rate among seeds and seedlings is usually density dependent (Davidar 1983, Howe 1989, Vander Wall 1990). Some authors reported that the consequences of seed aggregation in caches may result in higher seedling survival and thus by distinct multitrunked growth forms of adult trees (Bullock 1981, Linhart \& Tomback 1985). During seedling establishment, the number of stems per clump has been found to be negatively related to clump age for some species (Sherman \& Chilote 1972, Vander Wall 1992) and in consecutive years the clumps consisting of more than 1-2 stems became rare (Vander Wall 1990). The intraspecific competition for water between seedlings from a cache seems to be more distinctive in species that occupy arid sites. Vander Wall (1990) reported that mature piñon pines are rarely found in multiple-stemmed clumps like whitebark pine and limber pine, which occupy relatively more mesic sites. Multi-stemmed clumps in such conditions are usually reduced to a single seedling within a few growing years. As a consequence of high mortality in seedlings that are normally clump-dispersed, usually no more than one adult plant from a single clump survives (Howe 1989, Vander Wall 1990).

We found it interesting that the biggest height increment of seedlings was observed in the case of acorns sewed in fours (i.e., hypothesis \#2 was confirmed). So, the effect of seedling clumps on quantity (growth increment) and quality (mortality) characteristics seems to be reciprocal. Bullock (1981) also reported that seedlings growing in clumps had a higher biomass than those growing separately. We did not find support for the third hypothesis, where we stated that the increment of survived seedling increases after the death of other seedlings from the same cache. Seedlings from numerous caches had better growth increments, so there are no grounds for the "release effect" to occur.

In contrast to clump-dispersal (larder hoarding), the distinctive feature of scatter-dispersal for plant demography is that seeds normally germinate from several centimeters to many meters away from other seeds (Howe 1989). Not all studies reported that growing separately is better for sapling survival, but in some cases scatter-hoarding strategy of dispersal seems to be more effective and convenient from the ecological and parental tree point of view (Janzen 1970). Scattering of single acorns into separate caches seems to be the most effective anti-pathogen and anti-granivory strategy we can imagine. Scattering of hoarded food is also important for jays, since patchy distribution of caches containing single acorns are less susceptible to granivory. This evidence suggests that both participants (plant and bird) benefit from this strategy which is a kind of tradeoff between costs and benefits (Vander Wall 1990). Plants gain a higher seed and seedling survival and a more efficient dispersal effect (acorns cached separately), while the growth rate of seedlings is lower than in clumps. Scatter hoarding birds benefit lower hazard of cache loss from granivory, but must invest more energy in scattering the caches and retrieving them. Scattering seems to be clearly more beneficial for seedlings due to decreased mortality. Answering the question from the title, we can confirm that in the case of Quercus robur it is much more favourable for seedlings' survival that jays scatter their acorns rather than clump them.

\section{Acknowledgements}

We are grateful to the Forest Managers Janusz Jeznach and Grzegorz Wanat and to the staff of Nowe Ramuki Forest District, for great help, supporting and enabling us to conduct the research. We are also grateful to Fiona Milne-Rostkowska for the final language correction. The study was supported by grant number 240110 financed by the Polish Ministry of Science and Higher Education.

\section{References}

Augspurger CK, Kelly CK (1984). Pathogen mortality of tropical tree seedlings: experimental studies of the effects of dispersal distance, seedling density, and light conditions. Oecologia 61: 211-217. - doi: 10.1007/BF00396763

Bartlow AW, Kachmar M, Lichti N, Swihart RK, Stratford JA, Steele MA (2011). Does multiple seed loading in Blue Jays result in selective dispersal of smaller acorns? Integrative Zoology 6: 235-243. - doi: 10.1111/j.1749-4877.2011.00254.x Bossema I (1979). Jays and oaks: an eco-ethological study of a symbiosis. Behaviour 70: 1-117. doi: $10.1163 / 156853979$ X00016

Bullock SH (1981). Aggregation of Prunus ilicifolia (Rosaceae) during dispersal and its effect on survival and growth. Madrono 28: 94-95.

Chettleburgh MR (1952). Observations on the collection and burial of acorns by jays in Hainault Forest. British Birds 45: 359-364. [online] URL: http://britishbirds.co.uk/wp-content/uploa ds/article_files/V45/V45_N10/V45_N10_P359_36 4_A068.pdf

Danielewicz W, Kicinski P, Wiatrowska B (2016). Symptoms of the naturalisation of the Turkey oak (Quercus cerris L.) in Polish forests. Folia Forestalia Polonica, Series A Forestry 58: 147162. - doi: 10.1515/ffp-2016-0017

Davidar P (1983). Birds and neotropical mistletoes: effects on seedling recruitment. Oecolo- gia 60: 271-273. - doi: 10.1007/BF00379532 Dobrowolska D (2006). Oak natural regeneration and conversion processes in mixed Scots pine stands. Forestry 79: 503-513. - doi: 10.1093/ forestry/cplo34

Gómez JM (2003). Spatial patterns in long-distance dispersal of Quercus ilex acorns by jays in a heterogeneous landscape. Ecography 26: 573 584. - doi: 10.1034/j.1600-0587.2003.03586.x

Gómez JM (2004). Importance of microhabitat and acorn burial on Quercus ilex early recruitment: non-additive effects on multiple demographic processes. Plant Ecology 172: 287-297. doi: 10.1023/B:VEGE.0000026327.60991.f9

Howe HF (1989). Scatter- and clump-dispersal and seedling demography: hypothesis and implications. Oecologia 79: 417-426. - doi: 10.1007/ BFo0384323

Janzen DH (1970). Herbivores and the number of tree species in tropical forests. The American Naturalist 104: 501-528. - doi: 10.1086/282687 Jinks R, Mason B (1998). Effects of seedling density on the growth of Corsican pine (Pinus nigra var. maritima Melv.), Scots pine (Pinus sylvestris L.) and Douglas-fir (Pseudotsuga menziesii Franco) in containers. Annals of Forest Science 55: 407-423. - doi: 10.1051/forest:19980402 Johnson PS, Shifley SR, Rogers R (2009). The ecology and sylviculture of oaks. Centre for Agriculture and Bioscience International, Oxfordshire, Cambridge, UK, pp. 81-93.

Kollmann J, Schill H-P (1996). Spatial patterns of dispersal, seed predation and germination during colonization of abandoned grassland by Quercus petrea and Corylus avellana. Vegetatio 125: 193-205. - doi: 10.1007/BFo0044651

Kondracki J (2009). Geografia regionalna Polski [Regional geography of Poland]. PWN Publisher, Warsaw, Poland, pp. 103-107. [in Polish] Kurek P, Dobrowolska D (2016). Synzoochoryczne rozsiewanie zołędzi przez sójki Garrulus glandarius na powierzchniach zrebowych oraz pod drzewostanem [Acorns dispersal by jays Garrulus glandarius onto clear-cuts and under the forest canopy]. Sylwan 160: 512-518. [in Polish]

Lambers JHR, Clark JS, Beckage B (2002). Density-dependent mortality and the latitudinal gradient in species diversity. Nature 417: 732735. - doi: 10.1038/nature00809

Legg EW, Clayton NS (2014). Eurasian jays (Garrulus glandarius) conceal caches from onlookers. Animal Cognition 17: 1223-1226. - doi: 10.100 7/s10071-014-0743-2

Lenth RV (2016). Least-squares means: the R package Ismeans. Journal of Statistical Software 69: 1. [online] URL: http://www.jstatsoft. org/article/view/v069i01/0

Linhart YB, Tomback DF (1985). Seed dispersal by nutcrackers causes multi-trunk growth form in pines. Oecologia 67: 107-110. - doi: 10.1007/BF 00378458

Lu J, Johnson DJ, Qiao X, Lu Z, Wang Q, Jiang M (2015). Density dependence and habitat preference shape seedling survival in a subtropical forest in central China. Journal of Plant Ecology 8: 568-577. - doi: 10.1093/jpe/rtv020

McBride JR, Norberg E, Cheng S, Mossadegh A (1991). Seedling establishment of coast live oak in relation to seed caching by jays. General Technical Reports PSW-126, USDA Forest Ser- 
vice, Pacific Southwest Research Station, Berkeley, CA, USA, pp. 143-148. [online] URL: http://www.fs.usda.gov/treesearch/pubs/28411 Mosandl R, Kleinert A (1998). Development of oak (Quercus petraea (Matt.) Liebl.) emerged from bird-dispersal seeds under old-growth pine (Pinus sylvestris L.) stand. Forest Ecology and Management 106: 35-44. - doi: 10.1016/S037 8-1127(97)00237-5

Myczko I, Dylewski I, Zduniak P, Sparks TH, Tryjanowski $P$ (2014). Predation and dispersal of acorns by European Jay (Garrulus glandarius) differs between a native (Pedunculate Oak Quercus robur) and an introduced oak species (Northern Red Oak Quercus rubra) in Europe. Forest Ecology and Management 331: 35-39. doi: 10.1016/j.foreco.2014.07.027

Nilsson SG (1985). Ecological and evolutionary interactions between reproduction of beech $\mathrm{Fa}$ gus sylvatica and seed eating animals. Oikos 44: 157-164. - doi: 10.2307/3544057
Pons J, Pausas JG (2006). Oak regeneration in heterogeneous landscapes: the case of fragmented Quercus suber forests in the eastern Iberian Peninsula. Forest Ecology and Management 231: 196-204. - doi: 10.1016/j.foreco.2006. 05.049

Pons J, Pausas JG (2007). Acorn dispersal estimated by radio-tracking. Oecologia 153: 903911. - doi: 10.1007/s00442-007-0788-x

Pons J, Pausas JG (2008). Modeling jay (Garrulus glandarius) abundance and distribution for oak regeneration assessment in Mediterranean landscapes. Forest Ecology and Management 256: 578-584. - doi: 10.1016/j.foreco.2008.05.003 R Core Development Team (2016). R: a language and environment for statistical computing. $R$ Foundation for Statistical Computing, Vienna, Austria. [online] URL: http://www.r-project.org Seiwa K, Watanabe A, Saitoh T, Kannu H, Akasaka $S$ (2002). Effects of burying depth and seed size on seedling establishment of Japa- nese chestnuts, Castanea crenata. Forest Ecology and Management 164: 149-156. - doi: 10.101 6/S0378-1127(01)00607-7

Sherman RJ, Chilote WW (1972). Spatial and chronological patterns of Purshia tridentata as influenced by Pinus ponderosa. Ecology 53: 294298. - doi: 10.2307/1934085

Vander Wall SB (1990). Food hoarding in animals. The University of Chicago Press, Chicago, USA, pp. 178-198. [online] URL: http://books.google. com/books?id=AhlvmkSkxeYC

Vander Wall SB (1992). Establishment of Jeffrey pine seedlings from animal caches. Western Journal of Applied Forestry 7: 14-20. [online] URL: http://academic.oup.com/wjaf/article-abst ract/7/1/14/4772457

Wickham H (2009). ggplot2: Elegant graphics for data analysis. Springer-Verlag, New York, USA, pp. 1-90. 